Rosa M. CALCATERRA, Giovanni MADDALENA \& Giancarlo MARCHETTI (eds.), Il pragmatismo. Dalle origini agli sviluppi contemporanei

Roma, Carocci, 2015 (second edition 2017), 356 pages

\title{
Francesca Bordogna
}

\section{(2) OpenEdition}

\section{Journals}

Electronic version

URL: http://journals.openedition.org/ejpap/1011

DOI: 10.4000/ejpap.1011

ISSN: 2036-4091

Publisher

Associazione Pragma

Electronic reference

Francesca Bordogna, «Rosa M. calcaterRa, Giovanni maddalena \& Giancarlo marchetti (eds.), II pragmatismo. Dalle origini agli sviluppi contemporanei », European Journal of Pragmatism and American Philosophy [Online], IX-1 | 2017, Online since 22 July 2017, connection on 24 September 2020. URL http://journals.openedition.org/ejpap/1011 ; DOI : https://doi.org/10.4000/ejpap.1011

This text was automatically generated on 24 September 2020.

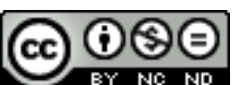

Author retains copyright and grants the European Journal of Pragmatism and American Philosophy right of first publication with the work simultaneously licensed under a Creative Commons AttributionNonCommercial-NoDerivatives 4.0 International License. 


\title{
Rosa M. CALCATERRA, Giovanni
} MADDALENA \& Giancarlo MARCHETTI (eds.), Il pragmatismo. Dalle origini agli sviluppi contemporanei

Roma, Carocci, 2015 (second edition 2017), 356 pages

\author{
Francesca Bordogna
}

\section{REFERENCES}

Rosa M. CALCATERRA, Giovanni MADDALENA \& Giancarlo MARCHETTI (eds.), Il pragmatismo. Dalle origini agli sviluppi contemporanei, Roma, Carocci, 2015 (second edition 2017), 356 pages

In February 1907 Giovanni Papini wrote on Leonardo that "Pragmatism" did not exist; there were "only pragmatist theories and more or less pragmatist thinkers." Rather than "a nice system born out of the brain of a single philosopher" or of "an homogeneous school," pragmatism was "a coalition of theories of various origins and nature." The rich pragmatist genealogy offered by Il pragmatismo. Dalle origini agli sviluppi contemporanei, edited by Rosa M. Calcaterra, Giovanni Maddalena and Giancarlo Marchetti, gathers together, as did the Florentine periodical in its days, the most diverse forms of pragmatism, including the controversial one developed by Papini and his friend Giuseppe Prezzolini. The authors move from the premise that the classical pragmatists and the wide variety of twentieth-century and contemporary thinkers discussed in the volume worked towards a "shared project." This premise could appear obvious, but it is not, not even if it is confined to Charles S. Peirce, William James, and John Dewey; on the contrary, it clashes with a long series of attempts aimed, as the editors remind us, to demonstrate that certain forms of pragmatism had nothing in common with others. 
2 Although the volume underlines the profound continuities between different types of pragmatism, it also highlights substantial differences in the ways in which the thinkers under consideration inflected pragmatist themes and doctrines. Thus, the pragmatic maxim, anti-foundationalism, fallibilism, the idea of the continuity between knowledge and reality, the conception of knowledge as an instrument for transforming reality, the "acceptance of evolutionary thinking," indeterminism, the flux of consciousness, the orientation towards the future, as well as notions of experience, practice, action, belief, and "novelty," emerge as constant, yet fluid traits, subject to radical transformations in the pragmatist tradition.

3 Il Pragmatismo provides important contributions on individual thinkers; yet, because of its emphasis on "family resemblances" and cross-references between chapters, it also lends itself to transversal readings, functioning as an encyclopedia of pragmatist themes, sensibilities, and attitudes. For example, readers interested in the centrality of notions of creativity to pragmatism can follow a path that begins with Anna Maria Nieddu's thoughts on Emersonian creativity and ends with Roberto Gronda's and Sarin Marchetti's reflections on the semantic, epistemic, and aesthetic conceptions of creativity articulated by Richard Bernstein, John McDermott, Joseph Margolis, Cornel West, Susan Haack, Robert Brandom, and Richard Shusterman. Along the way they will encounter an important Roycean notion of "productive creativity," unearthed by Rossella Fabbrichesi, and Giovanni Maddalena's and Maria Luisi's considerations on the relevance of creativity for Papini, Prezzolini, James, and F. C. S. Schiller.

Rich of new insights and perspectives on questions highly debated in the philosophical literature, such as, for example, the question of the relationships between pragmatism and Kant's transcendentalism, critical theory (a topic examined in depth by Mariannina Failla), and analytical philosophy, the book will also prove of interest to historians and philosophers of science. Massimo Ferrari, Rosa M. Calcaterra, Roberto Frega, Guido Baggio, and Giancarlo Marchetti explore the links between James's, Dewey's, Mead's, and Putnam's pragmatism and specific aspects of physiologically-oriented functionalist psychology (including James's and Dewey's psychologies), Wilhelm Wundt's psychological theory of language production, and behaviorism, a theme also prominent in Paolo Valore's essay on Quine. Anna Boncompagni examines Sydney Hook's extension of naturalism and of "the scientific method" from the natural sciences to "ethics, the social sciences, and the political life," while Andrea Tortoreto sheds light on Sellars" distinction between "manifest" and "scientific" images of man. Historians of mathematics will appreciate Giovanni Maddalena's sharp analysis of the different stages of the development of Peirce's thoughts on continuity (a topic Maddalena has explored extensively elsewhere) and his ability to show how the various "blocks of Peirce's thought" "progressively came to fit together," revealing "mutual correspondences" across disciplinary divides.

5 Written by philosophers, the history of pragmatism that emerges from this volume is, by and large, a philosophical history and, as such, it is quite different from intellectual, cultural, or political histories of this way of thinking, including those offered e.g. by James Kloppenberg, David A. Hollinger, James Livingston, Jeffrey Sklansky, and, more recently, Alexander Livingston. The pragmatist canon adopted by the authors and the historiographical principles underlying their work - such as, with a few important exceptions, the emphasis on the "idea" of practice rather than on the historical reconstruction of specific practices carried out by the historical actors, or the focus on 
thinkers who theorized pragmatism, rather than on people who lived pragmatism in their political or social actions or in their personal life regimens - serve philosophical purposes, including especially that of demonstrating the philosophical relevance of pragmatism today. Nevertheless, the authors explicitly acknowledge that "deciding who or what one should include into the history of pragmatism is [...] a way of determining the nature of its usefulness and of its influence on contemporary philosophy." This sincerity of intents is indicative of the profound historical sensibility that characterizes the Italian pragmatist school represented by the volume, enabling the authors to pursue their theoretical goals without sacrificing historical accuracy or losing sight of the historical situatedness of philosophical doctrines.

6 Exemplary, in this regard, are Massimo Ferrari's and Rosa M. Calcaterra contributions on William James and Richard Rorty. Ferrari locates the origins of James's pragmatism in early works by James, including pages that subsequently James built into The Principles of Psychology and the seminal essay "The Sentiment of Rationality," which James started composing as early as 1879 . In that essay James contended that the most important feature of a philosophical conception consists in its practical consequences, especially its ability to "banish uncertainty from the future." Ferrari sees in that "precept" a "crucial" moment in the development of James's interpretation of the pragmatic maxim, thus pushing the origins of his pragmatism back to the late 1870 s. This conclusion matters because it invites us to rethink the traditional chronology of American pragmatism, according to which this type of thinking was "inaugurated" by Peirce and resumed by James only in 1898. Rosa M. Calcaterra, one of the most interesting interpreters of Rortian philosophy today, succeeds both in providing a historically credible portrait of Rorty, a figure often caricaturized by contemporary philosophers, and in offering a novel reading of controversial aspects of Rorty's thought - such as his notions of "human conversation" and of solidarity -, thereby rescuing them from traditional "hasty readings" that have compromised their philosophical serviceability.

7 The authors do not evade the philosophical task of subjecting various kinds of philosophical claims to critical assessment; however, they resist the temptation of dividing the pragmatists in "good" and "bad" - a temptation which, in contrast, has led other philosophers to discredit certain varieties of pragmatism and to restrict the use of the term so as to exclude from the pragmatist canon Rorty and much of James's thought.

8 Il pragmatismo offers a genuinely pluralistic narrative, which, in the pragmatist spirit of active empathy, includes the most diverse forms of pragmatism, unearthing, case by case, the fluid and partial links between them. Ferrari reminds us that, to the a priori noetic and genetic forms of unity postulated by the absolute idealists, William James preferred forms of incomplete unity that emerged "piecemeal" in the course of experience. By showing the interconnection between radically different varieties of pragmatism, the authors, one could say quoting Ferrari, successfully avoided "closing the tale in a single story." James, for one, would have appreciated the product of their labors.

9 An important instrument for a wide array of scholars, the volume should be translated into English, so as to allow an international readership, already familiar with many of its authors, to experience through this collective work a different way of writing a philosophical history of pragmatism. 


\section{AUTHORS}

FRANCESCA BORDOGNA

University of Notre Dame

fbordog1[at]nd.edu 